\title{
EFFECT OF ENDOGENOUS PROTEASES ON GELATION OF RED TILE FISH SURIMI
}

\section{Kigen TAKAHASHI, Emiko OKAZAKI and Kazufumi OSAKO*)}

Department of Food Science and Technology, Tokyo University of Marine Science and Technology. Minato - ku, Tokyo 108-8477, Japan.

*e-mail: osako@kaiyodai.ac.jp

\begin{abstract}
Red tile fish Branchiostegus japonicus meat degrades easily. In market, the small-sized fish is traded at a low price. Additionally, the population of red tile fish in the sea around Japan has reduced. Therefore, for effective utilization of small-sized red tile fish, the effect of endogenous proteases on heat-induced gelation of red tile fish surimi was investigated in the research. Fish gels from red tile fish surimi were prepared at different temperatures between $30-90{ }^{\circ} \mathrm{C}$. After heating, the samples were cooled in ice water and then mechanical properties and SDS-PAGE patterns were analyzed. Homogenates prepared from the surimi were mixed with protease inhibitor solutions. The mixtures were incubated in water bathes at 40 or $60^{\circ} \mathrm{C}$. After heating, peptide contents in the supernatant and autolytic protein patterns were determined by the Lowry method and SDS-PAGE respectively. The surimi didn't form heat-induced gels at $30-80^{\circ} \mathrm{C}$ and SDS-PAGE showed that proteolysis markedly occurred. Addition of 1, 10-phenanthroline, benzamidine or SBTI prevented proteolysis. These results suggest that red tile fish surimi had extremely low gel-forming ability due to endogenous metalloprotease and trypsin-like serine protease.
\end{abstract}

Keywords: Fish products, Gelation, Protease inhibitor, Surimi

\section{INTRODUCTION}

Red tile fish is a popular fish as a food in Japan. However the fish meat has soft texture and degrades easily thus it is difficult to process red tile fish for seafood processers. Additionally small sized fish is traded cheaply in markets of Japan. Therefore it is necessary to find a good way for effective utilization mainly on small size of red tile fish.

Nowadays the demand of surimi products has increased in the world therefore it is important to develop a new material (Vidal-Giraud and Chateau 2007). In order to clarify the potential of surimi material, gel - forming ability of red tile fish surimi was investigated in this study.

Deep relationship between proteolysis due to endogenous proteases and heat - induced gelation is well known (An et al. 1996). Therefore the effect of endogenous proteases on gelation was also researched.

\section{MATERIAL AND METHODS}

\section{Material}

Red tile fish was caught in the sea around Nagasaki prefecture, Japan and delivered in the ice?to our laboratory. After arrival, the fishes were manually treated and then only the meat was collected. The meat was minced twice and then mixed well with $5 \%$ sucrose $(w / w)$ as 
a cryoprotectant. The minced meat at this step was called as surimi. Surimi was divided into small portions approximately $100 \mathrm{~g}$ and kept at $-30^{\circ} \mathrm{C}$ until use.

\section{Fish gel preparation}

Surimi was thawed in a refrigerator at $4{ }^{\circ} \mathrm{C}$. After thawing, surimi was ground for $10 \mathrm{~min}$ with cold ion exchanged water and continued with $3 \% \mathrm{NaCl}(\mathrm{w} / \mathrm{w})$ for $15 \mathrm{~min}$. Final moisture contents of ground surimi was adjusted to $81.0 \%$. Ground surimi paste was shaped into steel cases and heated at the different temperatures between 30 and $90^{\circ} \mathrm{C}$, respectively. After heating, the samples were cooled in ice water for $30 \mathrm{~min}$. Finally, mechanical properties and protein molecular weight distributions of fish gels were analyzed.

\section{Assay of endogenous protease activities}

$20 \mathrm{~g}$ of surimi was homogenized with $60 \mathrm{~mL}$ of Tris $\mathrm{HCl}(\mathrm{pH} 7.0) .2 \mathrm{~mL}$ of homogenates were mixed with $2 \mathrm{~mL}$ of protease inhibitor solutions. Final concentrations of inhibitors were designed as follow $10 \mathrm{mM} \mathrm{1,} \mathrm{10-phenanthroline,} 10 \mathrm{mM}$ benzamidine or $1.0 \mathrm{mg} / \mathrm{mL} \mathrm{SBTI}$. The mixtures were heated at $40^{\circ} \mathrm{C}$ or $60^{\circ} \mathrm{C}$ for $20 \mathrm{~min}$. After heating the samples were mixed with $2 \mathrm{ml}$ of $15 \% \mathrm{TCA}$ or dissolved in $20 \mathrm{ml}$ of $20 \mathrm{mM}$ Tris $\mathrm{HCl}$ (pH 8.8)-2\% sodium dodecyl sulphate (SDS)-8 M urea-2\% mercaptoethanol for SDS-PAGE analysis. The samples added with TCA were centrifuged at $4{ }^{\circ} \mathrm{C}$ and $10,000 \mathrm{~g}$ for $10 \mathrm{~min}$. The peptide contents of the supernatants were determined by the Lowry method (Lowry et al. 1970)

\section{Sodium dodecyl sulphate - polyacrylamide gel electrophoresis (SDS-PAGE) analysis}

The protein molecular weight distributions were analyzed by SDS-PAGE which was conducted according to the method of Laemmli (1970) using $10 \%$ polyacrylamide gels. The polyacrylamide gels were stained with $0.1 \%$ Coomassie Brilliant Blue R-250 in methanol/acetic acid/water $(30: 10: 60 \% \mathrm{v} / \mathrm{v})$, and then destained in methanol/acetic $\mathrm{acid} /$ water (30:10:60\% v/v).

\section{Mechanical property analysis}

Mechanical properties of gels were measured by a creep meter (RHEONER2, Yamaden Co., Ltd., Tokyo, Japan) equipped with a spherical plunger $(6.0 \mathrm{~mm}$ in diameter) with $1 \mathrm{~mm} / \mathrm{s}$ raising rate of the sample table.

\section{RESULTS AND DISCUSSION}

The surimi did not formed heat - induced gels at $30-80^{\circ} \mathrm{C}$ of heating conditions. The results of SDS-PAGE showed that proteolysis strongly occurred. Addition of 1, 10 phenanthroline, benzamidine or SBTI prevented the increase of peptide contents and proteolysis including MHC degradation. These results suggest that red tile fish surimi has low gel-forming ability due to endogenous metalloprotease and trypsin-like serine protease. 


\section{CONCLUSION}

Red tile fish had has low gel - forming ability due to proteolysis and it can be inhibited by protease inhibitor. Therefore red tile fish have a potential to be a material of surimi products and it is important to select natural protease inhibitors as food additives.

\section{REFERENCES}

An H, Peters MY, Seymour TA. 1996. Roles of endogenous enzymes in surimi gelation. Trends in Food Science \& Technology. 7: 321-327.

Laemmli UK. 1970 .Cleavage of structural proteins during the assembly of the head of bacteriophage T4. Nature. 227: 680-685.

Lowry OH, Rosebrough NJ, Farr AL, Randall RJ. 1951. Protein measurement with the Folin phenol reagent. J. Biol. Chem. 193: 265.

Vidal-Giraud B. Chateau D. 2007. World Surimi Market. GLOBEFISH. 89: 1-52. 